\title{
EDITORIAL
}

\section{Pharmacy, the continuously expanding field of science}

\section{Editor-in-Chief: Prof. Pál Perjési}

Institute of Pharmaceutical Chemistry, University of Pécs, Pécs, Hungary

\section{Check for updates}

Correspondence to: Pál Perjési, Institute of Pharmaceutical Chemistry, University of Pécs, Pécs, Hungary; Email: pal.perjesi@gytk.pte.hu

Received: January 15, 2022;

Accepted: January 15, 2022;

Published: January 17, 2022.

Citation: Perjési P. Pharmacy, the continuously expanding field of science. J Pharm Biopharm Res, 2022, 3(1): 185-186.

https://doi.org/10.25082/JPBR.2021.01.003

Copyright: (C) 2022 Pál Perjési. This is an open access article distributed under the terms of the Creative Commons Attribution License, which permits unrestricted use, distribution, and reproduction in any medium, provided the original author and source are credited.
"Pharmacy, the interdisciplinary field of science". This was the title of my opening editorial of the first issue of this Journal [1]. After the publication of the first three volumes, I am writing this editorial to present another intrinsic characteristics of Pharmacy and reflect on the first three years of the Journal of Pharmaceutical and Biopharmaceutical Research (JPBR).

Originating from the traditional herbal formulations, nowadays, Pharmacy covers all the disciplines focusing on the behavior of complex pharmaceutical forms, drug-releasing systems, and active compounds in the human body. Masters of pharmaceutical sciences must know the basics of pharmaceutical chemistry, pharmaceutical technology, biotechnology, biology, physiology, pharmacology, and toxicology.

Based on the differences of theory and practice of manufacturing, formulation, clinical trials, and applications of the present-day pharmaceutical products, it can be distinguished the classical small-molecular and biological drugs. Small molecules bind to a particular area of target proteins such as enzymes, receptors, or other proteins, mainly in an antagonistic way. It is estimated that out of the $\sim 20,000$ human proteins, only $\sim 3,000$ are druggable [2]. As of 2017, approved drugs targeted only 667 human proteins [3]. These figures call the attention of researchers partly to the unexplored protein targets, partly to the limitations of the small-molecule-based therapies.

Besides the dominance of the small-molecule drug developments, an increasing number of biological drugs have been developed and approved over the years. In 2019, for example, 10 of the 48 new FDA-approved drugs were biologics [4]. Among them, one can find five monoclonal antibodies and three antibody-drug conjugates. That year, three synthetic peptides and two oligonucleotides were also authorized.

In the last two years, mainly due to the COVID-19 pandemic, oligonucleotide-based therapies have become the focus of attention. Recombinant proteins have limitations as drugs, mainly due to size and stability issues. By contrast, nucleic acid-based strategies avoid many of these limitations. Examples of such therapeutic agents include oligonucleotides, plasmid DNA, $m \mathrm{RNA}$, ribozymes, and RNA $i$-related nucleic acids such as miRNA, siRNA, and short hairpin RNA (shRNA) [5].

The very first oligonucleotide therapies were DNA-based approaches. DNA drugs are stable enough to be delivered to the nuclei of the patient's cells to generate therapeutic proteins. They can be applied as plasmids or integrated into a viral vector. Such drugs are used to replace defective or missing proteins. Since the integration of foreign DNA (plasmid DNA) into the host's genetic material raised concerns, non-integrating strategies (using viral vectors) became the more commonly used approach [6].

RNA-based therapies are developed in three directions: (a) antisense RNA (RNA $i$; targeting DNA or RNA), (b) RNA aptamers (targeting proteins), and (c) messenger RNA ( $m$ RNA; encoding proteins). Successful development of RNA therapeutics had to overcome several significant hurdles, such as the (a) rapid degradation of exogenous RNA; (b) delivery of the negatively charged RNA across the hydrophobic cytoplasmic membranes; and (c) strong immunogenicity of the exogenous RNA [7]. Messenger RNA was discovered in 1961, but RNA therapies only took off in the1990s. The first RNA therapy, the antisense oligonucleotide fomivirsen, was approved in 1998 [8]. The history of development of the most important and profitable vaccines, the $m$ RNA-based COVID-19 vaccines, is summarized by Dolgin [9]. 
I opted for this short historical summary of the development of biopharmaceuticals to demonstrate the complexity and continuous expansion of pharmaceutical sciences. The above developments couldn't be accomplished without the cooperation of highly qualified experts in the main fields of pharmaceutical sciences mentioned above.

The Journal of Pharmaceutical and Biopharmaceutical Research (JPBR) is intended to provide scientists, researchers, and students worldwide with unlimited access to the latest advances of the pharmaceutical and biopharmaceutical research. So far, three volumes have appeared with 21 articles. By the time of writing this editorial, the published contributions collectively enjoyed 22,931 Abstract and 12,199 PDF downloads. In comparison, these figures are consistent with the Article Access Statistics of a sister journal, Chemical Reports, published by SyncSci Publishing over the period of three years (2019-2021).

So far, most of the published articles are related to studies with small-moleculebased therapies. The authors of the published articles are educational researchers from Austria, Canada, China, Egypt, Hungary, and Pakistan. Not a small measure of this achievement is the diligent work of the JPBR Editorial Board that consists of 36 members representing Brazil, China, Ecuador, Egypt, France, India, Iran, Italy, Macau, Republic of Korea, Singapore, Turkey, and the USA. Furthermore, several experts volunteered their time to peer review the submissions. As Editor-in-Chief, I take the opportunity to express my sincere gratitude to our authors, editorial board members, reviewers. I also wish to thank the sacrificial work of Ms. Snowy Wang, who is the Section Editor of the Journal.

I am closing this editorial with the hope that more and more scholars all over words will opt for the JPBR to publish their Original research works, Reviews, and Short communications on both the small-molecule and biological pharmaceuticals. The team mentioned above will do its best to provide as high level of acknowledgement of the published articles as possible.

\section{References}

[1] Perjési P. Pharmacy, the interdisciplinary field of science. Journal of Pharmaceutical and Biopharmaceutical Research, 2018, 1(1): 1-2. https://doi.org/10.25082/JPBR.2018.01.001

[2] Rodgers R, Austin C, Anderson J, et al. Glimmers in illuminating the druggable genome. Nature Reviews Drug Discovery, 2018, 17: 301-302. https://doi.org/10.1038/nrd.2017.252

[3] Santos R, Ursu O, Gaulton A, et al. A comprehensive map of molecular drug targets. Nature Reviews Drug Discovery, 2016, 16: 19-34. https://doi.org/10.1038/nrd.2016.230

[4] de la Torre BG and Albericio F. The pharmaceutical industry in 2019. An analysis of FDA drug approvals from the perspective of molecules. Molecules, 2020, 25(3): 745. https://doi.org/10.3390/molecules25030745

[5] Dammes N and Peer D. Paving the road for RNA therapeutics. Trends in Pharmacological Sciences, 2020, 41(10): 755-775. https://doi.org/10.1016/j.tips.2020.08.004

[6] Daley J. Gene therapy arrives. Nature, 2019, 576(7785): S12-S13. https://doi.org/10.1038/d41586-019-03716-9

[7] Damase TR, Sukhovershin R, Boada C, et al. The Limitless Future of RNA Therapeutics. Frontiers in Bioengineering and Biotechnology, 2021, 9: 628137. https://doi.org/10.1038/10.3389/fbioe.2021.628137

[8] DeWeerdt S. RNA therapies explained. Nature, 2019, 574: S2-S3. https://doi.org/10.1038/d41586-019-03068-4

[9] Dolgin E. The tangled history of mRNA vaccines. Nature, 2021, 597: 318-324. https://doi.org/10.1038/d41586-021-02483-w 